Журнал«Герспективитаінноваціїнаукиљ

(Серія«Гедагогіка», Серія«Гцихологія», Серія«Медицинв»

№2(7) 2022

УДК 004.38:681.32

https://doi.org/10.52058/2786-4952-2022-2(7)-914-923

Ніколасску Інна Олександрівна доктор педагогічних наук, доцент, т.в.о. завідувача кафедри дошкільної освіти, Черкаський національний університет імені Богдана Хмельницького, бул. Шевченка, 81, м. Черкаси, 18000, тел.: (0472) 372-142, https://orcid.org/0000-0002-9928-9291

Шинкарьова Валерія Сергіївна аспірант кафедри дошкільної освіти, Черкаський національний університет імені Богдана Хмельницького, бул. Шевченка, 81, м. Черкаси, 18000, тел.: (0472) 372-142, https://orcid.org/0000-0002-8439-446X

\title{
ЦИФРОВІЗАЦІЯ ОСВІТИ ЯК СУЧАСНА ВИМОГА ІНФОРМАЦІЙНОГО СУСПІЛЬСТВА
}

Анотація. Стаття порушує питання формування актуальних для інформаційного суспільства компетентностей у фахівців системи освіти, наголошує на об'єктивності і закономірності цифровізації освіти. Узагальнено, що тенденції цифрової трансформації освіти потребують грунтовної практикоорієнтованої підготовки педагогів, націлених на інтенсивне використання інформаційно-комунікаційних технологій у процесі виконання професійних обов'язків. Процес цифровізації обгрунтовано як конвергенцію цифрових технологій, матеріальних i соціально-гуманітарних практик. Виокремлено складові цифрового суспільства, що водночас слугують детермінантами побудови цифрового освітнього процесу. Висвітлено значення професійної підготовки майбутніх вихователів у контексті подальшого забезпечення наступності формування цифрової грамотності зростаючих поколінь починаючи 3 дошкільного віку. Зіставлено ключові компетентності, актуальні для працівників системи освіти, у відповідності до оновленого фреймворку Digital Competence.

Запропоновано шляхи підвищення ефективності реалізації цифрового освітнього процесу, зокрема шляхом імплементації засад цифрової дидактики. Узагальнено завдання, що постають до вирішення для підвищення рівня цифрової грамотності працівників системи освіти. Схарактеризовано низку особистісних особливостей представників цифрового покоління, а також наголошено на потребі істотної трансформації традиційного освітнього процесу відповідно до їх запитів.

Окреслено особливості побудови цифрового освітнього процесу в закладах вищої та дошкільної освіти, обгрунтовано значущість залучення до його реалізації висококваліфікованого кадрового потенціалу. На основі аналізу нормативних документів виділено основні умови цифровізації освіти, звернено 
увагу на інтеграцію елементів стандартів WorldSkills Ukraine та Worldskills International у освітньо-професійні програми підготовки майбутніх педагогів та вихователів.

Ключові слова: цифрова економіка, цифрова грамотність, система освіти, педагог, інформаційне середовище.

Nikolaesku Inna Oleksandrivna Doctor of Pedagogical Science, Associate professor at the Department of Preschool Education, Bogdan Khmelnytsky National University at Cherkasy, Shevchenko Blv., 81, Cherkasy, 18000, tel.: (0472) 372-142, https://orcid.org/0000-0002-9928-9291

Shynkarova Valeriia Serhiivna $\mathrm{PhD}$ student at the Department of Preschool Education, Bogdan Khmelnytsky National University at Cherkasy, Shevchenko Blv., 81, Cherkasy, 18000, tel.: (0472) 372-142, https://orcid.org/0000-0002-8439-446X

\section{DIGITIZATION OF EDUCATION AS A MODERN REQUIREMENT OF THE INFORMATION SOCIETY}

Abstract. The article raises the issue of forming relevant competencies for the information society in the education system, emphasizes the objectivity and regularity of digitalization of education. It is generalized that the tendencies of digital transformation of education require thorough practice-oriented training of teachers aimed at intensive use of information and communication technologies in the process of performing professional duties. The process of digitalization is justified as the convergence of digital technologies, material and socio-humanitarian practices. The components of the digital society are singled out, which at the same time serve as determinants of the construction of the digital educational process. The importance of professional training of future educators in the context of further ensuring the continuity of the formation of digital literacy of the growing generations from preschool age is highlighted. The key competencies relevant to employees of the education system are compared in accordance with the updated Digital Competence framework.

Ways to increase the efficiency of the digital educational process are proposed, in particular by implementing the principles of digital didactics. The tasks to be solved to increase the level of digital literacy of education workers are summarized. A number of personal characteristics of the digital generation are characterized, and the need for significant transformation of the traditional educational process in accordance with their needs is emphasized.

The peculiarities of building the digital educational process in institutions of higher and preschool education are outlined, the importance of involving highly qualified human resources in its implementation is substantiated. Based on the analysis of normative documents, the main conditions for digitalization of education are highlighted, attention is paid to the integration of elements of WorldSkills Ukraine 
and Worldskills International standards in educational and professional training programs for future teachers and educators.

Keywords: digital economy, digital literacy, education system, teacher, information environment.

Постановка проблеми. Нині базові види діяльності фахівців будь-якої професійної сфери реалізуються 3 урахуванням постійного вдосконалення загальної культури особистості. Погодимося з поглядами вчених, які у своїх дослідженнях зазначають, що в межах кожного напряму професійної підготовки мають формуватися та розвиватися ключові компетентності, які $\epsilon$ багатофункціональними, надпредметними та багатовимірними. Опанування таких компетентностей дозволяє ефективно виконувати обов'язки професійної діяльності та вирішувати іiі нагальні проблеми. Одними із найзатребуваніших компетентностей у інформаційному суспільстві постають інформаційнокомунікаційні. Інформатизація, а також новий етап розвитку - цифровізація освіти - є об'єктивною закономірністю розвитку сучасного суспільства. Відтак, фахівцям освітньої сфери необхідно вже опановувати інформаційнокомунікаційні та цифрові технології для їх подальшого застосування у професійній діяльності, тож одним з першочергових завдань системи освіти вважаємо формування цифрової грамотності майбутніх педагогів.

Аналіз останніх досліджень i публікацій. До питання цифрової трансформації суспільства звернені праці В. Бикова, Ю. Білоуса, О. Спіріна, А. Яцишиної та ін. Проблемі формування інформаційно-комунікаційної компетентності присвячені дослідження низки вітчизняних та зарубіжних вчених: Л. Босової, Л. Галкіної, Є. Козлової, М. Нобеля, В. Короповської, М. Лапчик, С. Олофа, Ф. Хортона та ін. Проблема формування цифрової грамотності майбутніх педагогів розглянута також вченими: А. Барановою, Н. Сршовою, Т. Панковою, Є. Хеннером, А. Шихмурзаєвою та ін.

Мета статті полягає в теоретичному обгрунтуванні актуальності процесу цифровізації системи освіти в Україні та узагальненні сучасних викликів інформаційного суспільства для всіх ланок неперервної освіти.

Виклад основного матеріалу. Аналіз наукової літератури свідчить, що у суспільстві інтенсивно зростає потреба у кваліфікованих фахівцях, які володіють професійною мобільністю i здатні працювати у соціально непередбачуваних умовах. Так, тенденції цифрової трансформації сфери освіти вимагають від педагога високого рівня інформаційно-комунікаційної компетентності та глибоких знань в галузі відповідних технологій для ефективної реалізації професійної діяльності, а також досить грунтовної практико-орієнтованої підготовки застосування інформаційно-комунікаційних технологій та сучасних освітніх технологій (онлайн-навчання (дистанційне), «змішане навчання» (blended learning), технології організації проєктної діяльності дітей для вирішення різних видів завдань [1]. Відповідно до Концепції розвитку цифрових компетентностей до 2025 року, затвердженого 
плану заходів щодо іiі реалізації, a також згідно законодавчих положень Міністерства та комітету цифрової трансформації України, система освіти $\epsilon$ одним із ключових інститутів, у межах якого створюються умови для розвитку цифрової грамотності. Наслідком цього є значні зміни у галузі освіти на всіх іiі рівнях. Сьогодні у численних наукових працях йдеться про завершення етапу інформатизації освіти, про перехід на новий рівень розвитку освітніх технологій. Новий етап розвитку суспільства отримав назву «цифровізація», який також називають сучасним трендом та пріоритетним напрямком модернізації української освіти, що змінює процес інформатизації.

Процес цифровізації $є$ глибокою конвергенцією цифрових технологій 3 матеріальними та соціально-гуманітарними технологіями та практиками, у тому числі освітніми. На думку Є. Стариченко, цифровізація в системі освіти спрямована на достачання безперервності процесу навчання (life long learning), i навіть його індивідуалізації з урахуванням технологій просунутого навчання (advanced learning technologies), які включають у процес навчання використання великих даних (big data), віртуалізації, віртуальної та доповненої реальності (VR, AR), хмарних обчислень, мобільних технологій та ін. [2]. Продуктивне впровадження цифрових технологій в освітній процес, залучення його суб'єктів у самостійний пошук, відбір інформації, проєктну діяльність - формує у зростаючих поколінь і майбутніх фахівців компетентності XXI століття, у тому числі цифрові. 3-поміж чинників, що обгрунтовують потребу у побудові цифрового освітнього процесу, вищої освіти та навчання, виступають три складові цифрового суспільства [3]:

- цифрове покоління (нове покоління дітей, що має особливі соціальнопсихологічні характеристики; «покоління Z», «діти процесора», «дітипланшетники», «діти-чіпи»);

- нові цифрові технології («передові», «розумні», «SMART»), що формують цифрове середовище та розвиваються в ньому (наприклад, телекомунікаційні технології; big data; технологіï розподіленого реєстру (зокрема блокчейн); штучний інтелект; інтернет речей; технологія цифрового сліду; віртуальна та доповнена реальність);

- цифрова економіка і нові вимоги до кадрів.

Врахування зазначених тенденцій особливо актуальне для навчання та професійної підготовки майбутніх педагогів закладів дошкільної освіти, вихователів, які покликані надалі готувати молоде покоління до життя та діяльності в сучасному цифровому суспільстві. Побудова системи цифрової освіти розглядається як значний пріоритет державної політики України, що відображений у стратегічних документах: Положенні про Єдиний державний веб-портал цифрової освіти «Дія. Цифрова освіта», Положенні про Національну освітню електронну платформу, Державній стратегії регіонального розвитку до 2027 року, Стратегії розвитку вищої освіти в Україні на 2021-2031 роки та ін.

Відтак майбутній вихователь під час забезпечення професійної діяльності в сучасних умовах має бути готовим до мотивованого використання всієї 
сукупності та різноманітності комп'ютерних засобів та цифрових технологій, що зумовлено низкою нових проєктів у рамках модернізації освіти. Відповідно, навчання майбутнього вихователя в закладі вищої освіти в даний час має здійснюватися на базі практико-орієнтованої підготовки із застосуванням інформаційно-комунікаційних та цифрових технологій, що трактує глибокі знання в галузі інформатики та інформаційно-комунікаційних технологій як фундамент для інноваційного розвитку, а також формування особистої ІКТкомпетентності, цифрової грамотності фахівця. Зауважимо, що від 2016 року функціонує оновлений фреймворк Digital Competence (DigComp 2.0), поданий Європейським Союзом, котрий містить наступні блоки значущих компетентностей:

- інформаційна i медіакомпетентність - знання, вміння, мотивація i відповідальність, пов’язані з пошуком, розумінням, організацією, архівуванням цифрової інформації та іiі критичним осмисленням, а також зі створенням інформаційних об'єктів 3 використанням цифрових ресурсів (текстових, зображувальних, аудіо та відео);

- комунікативна компетентність - знання, вміння, мотивація та відповідальність, необхідні для різних форм комунікацій (електронна пошта, чати, блоги, форуми, соціальні мережі та ін.) і з різними цілями;

- технічна компетентність - знання, вміння, мотивація та відповідальність, можливість ефективно та безпечно використовувати технічні і програмні засоби для вирішення різних задач, у тому числі використання комп’ютерних мереж, хмарних сервісів тощо;

- клієнтська компетентність - знання, вміння, мотивація та відповідальність, можливість вирішувати за допомогою цифрових пристроїв та Інтернету різні повсякденні завдання, пов'язані з конкретними життєвими ситуаціями, передбачуваним професійними обов'язками [4].

Для ефективної реалізації цифрового освітнього процесу в закладі освіти, він має бути заснований на інноваційній галузі педагогічної науки, зосібно на цифровій дидактиці - науковій дисципліні щодо організації освітнього процесу в цифровому середовищі. Предметом цифрової дидактики є діяльність людини, а не функціонування цифрових освітніх засобів. Як зазначає В. Блінов «цифрова дидактика може розглядатися як транс-інтегративна галузь наукового знання», що характеризується «взаємним перенесенням певних наукових ідей та підходів 3 однієї області до іншої, а також їхню інтеграцію» [5, с. 12]. Предметом цифрової дидактики вищої освіти та навчання $\epsilon$ взятий загалом процес навчання як система організації освітнього процесу в цифровому середовищі, включаючи цілі навчання (відповідно до вимог цифрової економіки та цифрового суспільства), зміст навчання та вимоги до його формування, способи організації процесу навчання (на основі використання можливостей цифрових технологій), організаційні форми, технології та методи навчання (максимальне використання дидактичних можливостей цифрових технологій), засоби навчання (у тому числі цифрові - мережеві та програмно-апаратні, об'єднані в єдиний інтелектуальний 
комплекс), вплив цифрового освітнього процесу вищої освіти та навчання на розвиток суспільства.

Вітчизняний дослідник I. Лопушинський у своїх наукових доробках наголошує на значущості наступних завдань щодо підвищення рівня цифрової грамотності та формування відповідних навичок майбутніх фахівців в межах державної освіти:

- аналіз ситуації. Проведення незалежних якісних та кількісних досліджень щодо доступності цифрових навичок для різних категорій населення, встановлення критеріїв впливу зовнішніх чинників на формування цифрових навичок, визначення основних перешкод у процесі використання цифрових технологій та специфічних інструментів;

- на основі наведеного аналізу має відбутись розробка профільними міністерствами переліку ключових цифрових навичок та компетенцій з метою забезпечення потреб цільових аудиторій окремих галузей;

- розробка якісного змісту освіти, перегляд та оновлення освітньопрофесійних програм;

- розробка та просування загальнодоступних дистанційних та аудиторних курсів цифрової грамотності, включаючи змішане навчання з метою охоплення численної кількості фахівців різних категорій;

- вимірювання та сертифікація цифрової грамотності та цифрових навичок. Адаптація передової методології такого вимірювання та імплементація незалежної сертифікації у відповідності до запиту ринку праці;

- перегляд нормативної бази, яка визначає i регулює процедуру сертифікації цифрової грамотності та цифрових навичок фахівців усіх сегментів, 3 урахуванням міжнародних вимог, а також врегулювання нормативної бази, що передбачає підвищення заробітної плати фахівця, який підтвердив відповідний рівень цифрових компетенцій;

- визначення категорій професій, які передбачають обов'язкове запровадження цифрових компетенцій;

- пропагування значущості цифрової грамотності серед населення [6].

Варто зважати, що у даний час учасниками освітнього процесу є діти, що належать до «цифрового покоління». Вчені наголошують, що це покоління виросло в цифровому середовищі, зумовленому розвитком цифрових технологій. Науковець А. Вербицький зазначає, що поняття «цифрове покоління» виникло в рамках теорії поколінь, запропонованої М. Хоувом та В. Штраусом. Згідно з цією теорією, цінності поколінь складаються під впливом умов життя та виховання дитини до 12-14 років, вони визначають формування особистості і впливають на життя, діяльність і поведінку людей. Вчений виділив низку особливостей представників цифрового покоління: спілкування за допомогою мобільних телефонів та комп'ютерів; переважання віртуального спілкування над особистим; використання візуальної мови при віртуальному спілкуванні; зростання швидкості сприйняття інформації, проте скрутне утримання уваги на одному предметі; спосіб мислення відрізняється 
фрагментарністю, а судження - поверховістю; «кліпове мислення» (від англ. «to clip» - обрізати, обривати, робити вирізки), що складається у «цифровому просторі» життя дітей та підлітків [7]. Вчені зазначають, що стратегія роботи 3 представниками цифрового покоління повинна виходити 3 того, що їх практично неможливо інтегрувати в традиційний освітній процес. Необхідна істотна трансформація, результатом якої стає побудова нового, цифрового освітнього процесу. Для освітніх організацій цифрова трансформація має означати:

- зміну (оновлення) цілей і змісту освітньої роботи, орієнтування на максимальне розкриття потенціалу кожного суб'єкта навчання;

- перехід від навчання і виховання всіх до навчання і виховання кожного, змінюючи для цього організацію та методи освітньої діяльності;

- перегляд та оптимізацію комплектів навчально-методичних та організаційних рішень, інформаційних матеріалів, інструментів та сервисів;

- опис/рефлексію та оптимізацію використовуваних бізнес-процесів, їх побудову на засадах відкритості (зрозумілості) для всіх стейкхолдерів (перш за все для суб'єктів навчання і педагогів), встановлення їх більш гнучкими, масштабними та природними за своїм характером;

- використання всіх можливостей сучасних цифрових технологій для механізації та автоматизації бізнес-процесів і всіх видів роботи з інформацією 3 метою підвищення результативності і продуктивності освітнього процесу [8].

Особливістю побудови цифрового освітнього процесу в закладах вищої освіти $\epsilon$ впровадження та використання цифрових технологій, що вирізняються наступними дидактичними властивостями: свобода пошуку різної інформації в глобальній мережі; персоналізованість (необмежені можливості для персонального налаштування відповідно до потреб та особливостей дітей); інтерактивність (забезпечення багатосуб'єктності у процесі навчальної взаємодії); мультимедійність (комплексне залучення різних каналів сприйняття інформації); гіпертекстовість (вільне переміщення за текстом, використання перехресних посилань, довідковий характер інформації тощо); субкультурність (відповідність звичного образу світу для цифрового покоління) [1]. Значну роль у цифровому освітньому процесі закладів дошкільної освіти нині відіграють сучасні цифрові освітні технології (гейміфікація, мобільне навчання, змішане навчання, онлайн навчання, дистанційні освітні технології та ін.), що грунтуються на використанні різноманітних технічних засобів і спеціалізованого інтерактивного обладнання (ноутбуки, персональні комп'ютери, планшети, електронні фліпчарти, інтерактивні дошки, робототехнічні набори, інтерактивні пісочниці, інтерактивні клуби, інтерактивна підлога та ін.) [9].

Також для організації цифрового освітнього процесу у закладах освіти необхідний підготовлений висококваліфікований кадровий потенціал. Науковиці Г. Пєшкова та А. Самаріна відзначають, що саме кадровий потенціал, який володіє необхідними компетенціями в умовах постійно зростаючої 
цифровізації всіх сфер суспільства, може стати головним джерелом зростання його конкурентоспроможності. Для підготовки такого персоналу необхідно належним чином модернізувати систему вищої освіти, привести освітньопрофесійні програми у відповідність до потреб цифрової економіки, широко впровадити цифрові технології в освітній процес закладів освіти, забезпечити можливість навчання громадян протягом усього життя [10].

Відтак, викладачі, котрі забезпечують професійну підготовку майбутніх педагогів та володіють високим рівнем професійної компетентності, у тому числі ІКТ-компетентності, повинні враховувати принципово нові виховні завдання, які ставить перед освітою цифрова епоха: розвиток готовності до безперервних змін, що потребує певної трансформації звичної системи цінностей; виховання соціальної відповідальності у системі відносин «людина цифрові засоби - суспільство»; формування внутрішньої межі між віртуальними та реальними світами, розвиток здатності диференціювати ці світи та відповідні їм типи відповідальності; розвиток здатності критично аналізувати інформацію та фільтрувати інформаційний шум, рекламу тощо.

Навчання майбутніх педагогів та вихователів у системі вищої освіти в аспекті проблеми формування цифрової компетентності, цифрової грамотності значною мірою залежить від психолого-педагогічних, дидактичних, методичних та змістовних можливостей організації освітнього процесу, створення в освітній організації сучасного інформаційно-освітнього середовища [11]. Актуальність та значимість інформаційно-освітнього середовища освітніх організацій відображена у законодавчих, нормативно-методичних документах, регламентах, a також локальних нормативних документах освітньої організації. Так, інформаційно-освітнє середовище розуміємо як систему, що включає електронні інформаційні джерела, електронні освітні ресурси, комплекс інформаційних технологій, телекомунікаційних технологій, відповідних технологічних засобів і забезпечує освоєння студентами освітньо-професійних програм у повному обсязі незалежно від їх територіального розташування. Таким чином, вона $є$ основою для формування цифрової компетентності та цифрової грамотності майбутніх освітян.

Аналіз нормативних документів, рекомендацій та наукових досліджень дозволив виділити основні умови цифровізації освіти, до яких можна віднести:

- цифрове покоління дітей;

- створення законодавчої бази для цифровізації освіти;

- ресурсне забезпечення цифровізації освіти, що включає цифрове освітнє середовище закладу освіти;

- підготовка кадрового потенціалу цифрової освіти, що володіє ІКТ-компетентністю, котра включає цифрову грамотність;

- цифрові педагогічні технології та освітньо значущі цифрові технології.

Нині під час розробки освітньо-професійних програм підготовки майбутніх вихователів закладів дошкільної освіти доцільно поєднувати їх професійні стандарти зі стандартами WorldSkills Ukraine та Worldskills International 3 
урахуванням умов цифровізації освіти, передових світових практик, спрямованих на формування професійних компетенцій фахівців, зокрема у сфері дошкільного виховання для комплексного оволодіння навичками формування цифрової грамотності у дітей дошкільного віку. Основою взаємодії та сполучення положень цих стандартів має бути професійна компетентність освітянина, а однією 3 iii ключових компонентів і обов'язковою складовою підготовки майбутнього педагога має стати його цифрова компетентність, що $є$ вмінням, здатністю та готовністю вирішувати професійні завдання, використовуючи засоби IKT та освітньо значущі цифрові технології у професійній діяльності.

Висновки. Аналіз нормативних документів, рекомендацій, наукових досліджень у галузі цифровізації суспільства в цілому, дає можливість підкреслити значущість: особливостей виховання цифрового покоління дітей; потреби створення законодавчої бази для цифровізації освіти, ресурсного забезпечення цифровізації освіти, що включає цифрове освітнє середовище освітньої організації; підготовки кадрового потенціалу цифрової економіки, який володіє ІКТ-компетентністю, що включає й цифрову грамотність; цифрових педагогічних технологій та освітньо значущих цифрових технологій (великі дані, системи розподіленого реєстру, штучний інтелект, компоненти робототехніки, технології бездротового зв'язку, технології віртуальної та доповненої реальностей, технології цифрового двійника, технології електронної ідентифікації та аутентифікації, цифрові технології спеціалізованого освітнього призначення). Підсумовуємо, що ефективність цифровізації освіти взаємозалежна 3 наявним рівнем цифрової грамотності майбутніх фахівців, професійна підготовка яких має вже відбуватись 3 урахуванням міждисциплінарної інтеграції та умов цифровізації, за допомогою педагогів, котрі забезпечують і реалізують освітній процес у закладі вищої освіти відповідно до сучасних вимог суспільства.

\section{Лimepamypa:}

1. Гаврілова Л. Г., Топольник Я. В. Цифрова культура, цифрова грамотність, цифрова компетентність як сучасні освітні феномени. Інформаційні технологї̈ і засоби навчання. 2017. T. 61. № 5. C. 1-14.

2. Стариченко Б. Е. Цифровизация образования: реалии и проблемы. Педагогическое образование. 2020. №4. С. 16-26.

3. Трифонова О. М. Інформаційно-цифрова компетентність: зарубіжний та вітчизняний досвід. Наукові записки Центрально украӥнського державного педагогічного університету імені Володимира Винниченка. 2018. Вип. 173 (2). С. 221-225.

4. DigComp 2.0: The Digital Competence Framework for Citizens. 2016. [Електронний pecypc]. Режим доступу: https://ec.europa.eu/jrc/en/digcomp/digital-competence-framework

5. Блінов В. І. Основні ідеї дидактичної концепції цифрової професійної освіти і навчання. Харків: Вид-во «Перо», 2019. 24 с.

6. Лопушинський І. П. «Цифровізація» освіти в контексті розвитку інформаційного суспільства в Україні. Педагогічний альманах. 2018. Вип. 37. С. 46-55.

7. Вербицкий А. А. Цифровое обучение: проблемы, риски и перспективы. Ното Cyberus. 2019. № 1(6). [Електронний ресурс]. Режим доступу: http://journal.homocyberus.ru/ Verbitskiy_AA_1_2019. 
8. Потюк I. Є. Цифрова компетентність як складова професійної компетентності сучасного фахівця. Актуальні проблеми лінгводидактики в сучасному освітньому середовищі. Тернопіль, 2020. № 4. С. 25-27.

9. Жерновникова О. А. Технологія формування цифрової компетентності засобами гейміфікації. Інформаційні технологї̈ $і$ засоби навчання, 2020. Т. 75 . № 1.348 с.

10. Пєшкова Г. Ю., Самаріна А. Ю. Цифрова економіка і кадровий потенціал: стратегічний взаємозв'язок і перспективи. Освіта і наука. 2018. Вип. 20(10). С. 50-75.

11. Волкова Н. П., Лебідь О.В.Формування цифрової компетентності у майбутніх учителів гуманітарних спеціальностей. Педагогіка формування творчої особистості у вищій i загальноосвітній школах. 2021. Вип. 78. С. 161-166.

\section{References:}

1. Havrilova, L. H., Topolnyk, Ya. V. (2017). Tsyfrova kultura, tsyfrova hramotnist, tsyfrova kompetentnist yak suchasni osvitni fenomeny [Digital culture, digital literacy, digital competence as modern educational phenomena]. Informatsiini tekhnolohii $i$ zasoby navchannia Information technologies and teaching aids. 61 (5). 1-14 [in Ukrainian].

2. Starichenko, B. E. (2020). Cifrovizacija obrazovanija: realii i problemy [Digitalization of education: realities and problems]. Pedagogicheskoe obrazovanie - Teacher Education. 4. 16-26 [in Russian].

3. Tryfonova, O. M. (2018). Informatsiino-tsyfrova kompetentnist: zarubizhnyi ta vitchyznianyi dosvid [Information and digital competence: foreign and domestic experience]. Naukovi zapysky Tsentralno ukrainskoho derzhavnoho pedahohichnoho universytetu imeni Volodymyra Vynnychenka - Scientific notes of the Central Ukrainian State Pedagogical University named after Volodymyr Vynnychenko. 173 (2). 221-225 [in Ukrainian].

4. DigComp 2.0: The Digital Competence Framework for Citizens (2016). Retrieved from https://ec.europa.eu/jrc/en/digcomp/digital-competence-framework

5. Blinov, V. I. (2019). Osnovni idei dydaktychnoi kontseptsii tsyfrovoi profesiinoi osvity i navchannia [The main ideas of the didactic concept of digital vocational education and training]. Kharkiv: Vyd-vo «Pero». 24 [in Ukrainian].

6. Lopushynskyi, I. P. (2018). «Tsyfrovizatsiia» osvity v konteksti rozvytku informatsiinoho suspilstva v Ukraini [«Digitalization» of education in the context of the development of the information society in Ukraine]. Pedahohichnyi almanakh - Pedagogical almanac. 37. 46-55 [in Ukrainian].

7. Verbickij, A. A. (2019). Cifrovoe obuchenie: problemy, riski i perspektivy [Digital Learning: Problems, Risks and Prospect]. Homo Cyberus - Homo Cyberus. 1(6). Retrieved from http://journal.homocyberus.ru/Verbitskiy_AA_1_2019 [in Russian].

8. Potiuk, I. Ye. (2020). Tsyfrova kompetentnist yak skladova profesiinoi kompetentnosti suchasnoho fakhivtsia [Digital competence as a component of professional competence of a modern specialist]. Aktualni problemy linhvodydaktyky v suchasnomu osvitnomu seredovyshchi - Current problems of language didactics in the modern educational environment. 4. 25-27 [in Ukrainian].

9. Zhernovnykova, O. A. (2020). Tekhnolohiia formuvannia tsyfrovoi kompetentnosti zasobamy heimifikatsii [Technology of formation of digital competence by means of gamification]. Informatsiini tekhnolohii i zasoby navchannia - Information technologies and teaching aids. 75 (1). 348 [in Ukrainian].

10. Pieshkova, H. Yu., Samarina, A. Yu. (2018). Tsyfrova ekonomika i kadrovyi potentsial: stratehichnyi vzaiemozviazok i perspektyvy [Digital Economy and Human Resources: Strategic Relationships and Prospects]. Osvita i nauka - Education and science. 20(10). 50-75 [in Ukrainian].

11. Volkova, N. P., Lebid, O. V. (2021). Formuvannia tsyfrovoi kompetentnosti u maibutnikh uchyteliv humanitarnykh spetsialnostei [Formation of digital competence in future teachers of humanities]. Pedahohika formuvannia tvorchoi osobystosti u vyshchii $i$ zahalnoosvitnii shkolakh - Pedagogy of creative personality formation in higher and general education schools. 78. 161-166 [in Ukrainian]. 